\title{
Effects of Tolbutamide on Growth and Body Composition of Nondiabetic Children with Cystic Fibrosis
}

\author{
W. B. ZIPF, C. L. KIEN, C. A. HORSWILL, K. S. MCCOY, T. O'DORISIO, AND B. L. PINYERD \\ Divisions of Endocrinology, Nutrition, and Pulmonary, Department of Pediatrics, The Ohio State University \\ College of Medicine and Columbus Children's Hospital and Department of Internal Medicine. The Ohio State \\ University College of Medicine, Columbus, Ohio 43205
}

\begin{abstract}
Previously, we reported that nondiabetic children with cystic fibrosis show a blunted insulin response to a meal stimulus. In the study presented here, using tolbutamide, we determined the effects of augmented insulin secretion/action on height and lean body mass of children with cystic fibrosis. Twelve subjects (mean \pm SEM age, $11.0 \pm 0.5 \mathrm{y}$ ) were studied for three 4-mo periods: 1) pretreatment, 2) treatment, consisting of 750 $\mathrm{mg} / \mathrm{d}$ of tolbutamide, and 3) posttreatment. Before the pretreatment period, insulin response to a meal stimulus was evaluated in relation to three doses of tolbutamide: 0 , 250 , and $500 \mathrm{mg}$. Growth was monitored during each period, and incremental changes in lean body mass were calculated from height data. To validate the change in lean body mass based on height measurements, we determined lean body mass in seven subjects during the treatment period by using a criterion method $\left(\mathrm{H}_{2}{ }^{18} \mathrm{O}\right)$. Growth velocity $(\mathrm{cm} / 4 \mathrm{mo})$ significantly increased $(p<0.05)$ during the treatment $(2.58 \pm 0.31)$ compared with the pretreatment period $(0.88 \pm 0.20)$. The increase in lean body mass calculated from height was greater during the treatment $(1.61 \pm 0.29 \mathrm{~kg} / 4 \mathrm{mo})$ than during the pretreatment period $(0.44 \pm 0.18 \mathrm{~kg} / 4 \mathrm{mo})(p<0.05)$. There was also a significant increase $(p<0.05)$ in lean body mass during the treatment as measured with $\mathrm{H}_{2}{ }^{18} \mathrm{O}(1.91 \pm 0.65 \mathrm{~kg} / 4$ mo). Acute administration of either 250 or $500 \mathrm{mg}$ of tolbutamide reduced $(p<0.05)$ the area under the glucose concentration curve in response to a meal compared with the control condition of no tolbutamide. However, there was no significant effect of tolbutamide on plasma insulin levels. We conclude that short-term tolbutamide therapy more than doubled linear growth and increased lean body mass accretion 4-fold in slowly growing children with cystic fibrosis, possibly by improving the tissue response to insulin. (Pediatr Res 30: 309-314, 1991)
\end{abstract}

Abbreviations

CF, cystic fibrosis

$\mathrm{H}_{2}{ }^{18} \mathrm{O}$, isotopic form of water in which oxygen has an atomic weight of 18

LBM, lean body mass

TBW, total body water

CSC, Clinical Studies Center

ANOVA, analysis of yariance

AUC, area under the curve

Received Fehruary 12,1991: accepted June 18,1991

Correspondence and reprint requests: Dr. William B. Zipf, B-5 15 Endocrinology, Children's Hospital, 700 Children's Drive. Columbus. OH 43205.

Supported in part by a grant from the Cystic Fibrosis Foundation and NIH GCRC Grant RR-34
Rx, treatment

Pre-Rx, pretreatment control

Post-Rx, posttreatment control

Malnutrition in children with $\mathrm{CF}$ is associated with poor pulmonary function, poor immune function, and poor growth (1-4). The cause of the malnutrition in CF may be a consequence not only of malabsorption but also of inadequate intake and increased energy expenditure (5-7). Aggressive nutritional therapy in patients with $\mathrm{CF}$ has contributed to improvements in pulmonary function, immune response, growth, the overall clinical course, and survival $(1-4,8,9)$. However, in practice, high energy intakes may be difficult to achieve in some patients.

Functional insulin deficiency is a secondary complication of $\mathrm{CF}$. It has been estimated that $40 \%$ of $C F$ patients show glucose intolerance $(10,11)$ and low insulin levels in response to oral glucose tolerance tests $(10,12)$. Similarly, glucose intolerance and insulin deficiency have been observed during meal stimulation tests (13) and during i.v. glucose tolerance tests (14). Insulin deficiency is associated with significant abnormalities in the secretion of other pancreatic hormones including gastrointestinal peptide and pancreatic polypeptide $(13,14)$; however, we have demonstrated that, with the ingestion of a high-calorie meal, insulin and gastrointestinal peptide secretion can be increased (13). A nutritionally induced improvement in insulin secretion therefore could contribute to the observed improved growth and nutritional status directly by enhancing glucose utilization or via indirect effects on protein and amino acid metabolism (15-18).

The purpose of this study was to examine the effects of a 4 mo trial of Rx with tolbutamide on the growth and glucose homeostasis of children with $\mathrm{CF}$ to test the hypothesis that increased growth and LBM accretion could be enhanced as a result of increased insulin secretion or enhanced insulin action.

\section{MATERIALS AND METHODS}

Subjects were recruited from the CF patient population at Children's Hospital. None of the subjects were diabetic or had evidence of glucosuria. Procedures and risks were explained to the subjects and their parents. Before participation, written informed consent was obtained from the subjects and their parents, and verbal assent was obtained from the children. The study was approved by the institutional review board for use of human subjects in research.

Design and treatment. Subjects were studied for three consecutive, 4-mo periods. The first period was a Pre-Rx period (mo 0 to 4 ). The second period was the Rx period (mo 4 to 8 ) in which the subjects consumed $750 \mathrm{mg}$ of tolbutamide (Orinase; Upjohn 
$\mathrm{Co}$, Kalamazoo, MI) per day in two doses $(500 \mathrm{mg}$ in the morning and $250 \mathrm{mg}$ in the afternoon). The final 4 -mo period served as a Post-Rx period (mo 8 to 12 ).

$\mathrm{Rx}$ with tolbutamide was commenced at various times of the year (number of subjects beginning $\mathrm{Rx}$ during that period): January to March (2); April to June (0); July to September (6); and October to December (4).

Stature and weight. Throughout the study, subjects reported to the CSC in the fasted state once a month for the measurement of height and weight. Height was measured three consecutive times by the same technician by using a standardized position of the patient and a stadiometer (Holtain Unlimited, Crymmych, Wales, United Kingdom). For this technician, the average $( \pm \mathrm{SD})$ coefficient of variation for three consecutive height measurements on six subjects was $0.097 \pm 0.074 \%$ (range, 0.00 to $0.20 \%$ ). Weight was measured by using a calibrated balance scale.

Body composition. LBM was assessed in two ways. By using the equations of Slaughter et al. (19), which relate measured LBM to measured height, we estimated LBM by the height measurements at mo $0,4,8$, and 12. Rates of LBM accretion per 4 mo were calculated from the differences between mo 0 and 4 (Pre-Rx), mo 4 and 8 (Rx), and mo 8 and 12 (Post-Rx). We directly assessed LBM by using TBW measurements on seven subjects just before beginning $\mathrm{Rx}(\mathrm{mo} 4)$ and at the end of $\mathrm{Rx}$ (mo 8). Subjects reported to the CSC, voided, were weighed, and had baseline samples of saliva collected. After baseline sampling, subjects consumed a premeasured quantity of ${ }^{18} \mathrm{O}$-labeled water $(0.6 \mathrm{~g} / \mathrm{kg})$ of $\mathrm{H}_{2}{ }^{18} \mathrm{O}$ (12.1 atom percent; Iso-Tech, Inc., Miamisburg, $\mathrm{OH})$; the tracer was analyzed in our laboratory to verify enrichment. At 2, 3, and $4 \mathrm{~h}$ after the administration of the labeled water, saliva was collected and analyzed for ${ }^{18} \mathrm{O}$ content with a Finnigan MAT Delta E gas isotope ratio mass spectrometer (Finnigan MAT, San Jose, CA). The reproducibility (mean $\pm \mathrm{SD}$ ) of triplicate saliva measurements of the isotopic abundance of water $\left(\delta^{18} \mathrm{O}\right)$ at natural abundance was $5.402 \pm 0.187$ atoms per million atoms (coefficient of variation, 3.5\%). For enriched saliva samples $(n=6)$, the comparable values were $61.316 \pm 0.581$ atoms per million atoms $(0.95 \%)$. The isotopic enrichment was used to calculate TBW by using the formula of Schoeller et al. (20):

$$
\mathrm{TBW}=\frac{\mathrm{d}}{\mathrm{MW}} \times \frac{\mathrm{APE}}{100} \times 18.02 \times \frac{1.0407}{\mathrm{R}_{\mathrm{pdb}} \times \Delta \delta_{\mathrm{pdb}}{ }^{18} \mathrm{O}}
$$

where $\mathrm{d}$ is the dose of $\mathrm{H}_{2}{ }^{18} \mathrm{O}$ ingested in grams, $\mathrm{MW}$ is the molecular weight of the $\mathrm{H}_{2}{ }^{18} \mathrm{O}, \mathrm{APE}$ is the atoms percent enrichment of ${ }^{18} \mathrm{O}, 18.02$ is the atomic weight of ${ }^{18} \mathrm{O}, 1.0407$ is the $\mathrm{O}_{2}$ isotopic fractionation between $\mathrm{CO}_{2}$ and $\mathrm{H}_{2} \mathrm{O}$ at $25^{\circ} \mathrm{C}, \mathrm{R}_{\mathrm{pdb}}$ is the ratio of ${ }^{18} \mathrm{O}$ to ${ }^{16} \mathrm{O}$ in the Pee Dee Belemnite standard, and $\Delta \delta_{\text {pdb }}$ ${ }^{18} \mathrm{O}$, in units of atoms per million atoms, is the ${ }^{18} \mathrm{O}$ enrichment over baseline in the saliva $3 \mathrm{~h}$ after tracer ingestion. LBM was calculated assuming that $75.2 \%$ of the LBM of children is water (21).

Dose response. At mo 0 and on 3 separate days, subjects reported to the CSC after an overnight fast and received either 0,250 , or $500 \mathrm{mg}$ of tolbutamide. Ninety minutes after the dose of tolbutamide, subjects consumed a standardized liquid meal (Meritene; Sandoz Nutrition, Minneapolis, MN) containing 400 $\mathrm{kcal} / \mathrm{m}^{2}$, of which $36.0,30.6$, and $33.4 \%$ of the total calories were supplied by protein, fat, and carbohydrate, respectively. Blood samples were drawn at min $0,5,15,30,45,60,90,120$, and 180 after the meal. For the 250 - and $500-\mathrm{mg}$ tests, blood samples were also drawn at $90(-90)$ and $30 \mathrm{~min}(-30)$ before ingestion of the meal; these times corresponded to 0 and $60 \mathrm{~min}$ posttolbutamide ingestion, respectively. Blood samples were analyzed for glucose (coupled enzyme assay with hexokinase and glucose-6-phosphate dehydrogenase; Instrumentation Laboratory, Inc., Lexington, MA), insulin (RIA; Corning, Medfield, MA), and C-peptide (RIA; Immunex, Carson City, NV). Total AUC was calculated by triangulation.
Twenty-four $h$ profile of insulin. Subjects were admitted to the General Clinical Research Center at mo 0, before the Pre-Rx period, and again at the end of mo 8 when still receiving the Rx. Comparisons of peak insulin values and the 24-h integrated insulin area were made between the two periods. After an overnight fast, an indwelling catheter was placed in a forearm vein of the subject. During the next $24 \mathrm{~h}$, blood samples were drawn every $60 \mathrm{~min}$ between mealtimes during the day, every $30 \mathrm{~min}$ after a meal for $1 \mathrm{~h}$, and every $2 \mathrm{~h}$ during the night. Serum blood samples (total of 27) were analyzed for insulin.

$I G F$. Identical-volume aliquots of serum from each sample collected during the 24 -h period of insulin profiling were pooled to ensure adequate sample volume. The pooled sample was analyzed for concentrations of IGF-I and IGF-II (Endocrine Sciences, Van Nuys, CA). IGF-I and IGF-II values were transformed to $\mathrm{z}$ scores to account for normal age-related differences. Data provided by Endocrine Sciences were used to make the transformations.

Dietary intake. For $4 \mathrm{~d}$ (Thursday through Sunday) during each of the three periods of the study, subjects recorded daily food intake. Instructions were given to each patient on how to keep accurate records, and the parents assisted the patients in identifying, quantifying, and recording the foods consumed. Dietary records were analyzed by using data from Bowes and Church (22). For each 4-d period, the average values of the daily intake of energy, carbohydrate, protein, and fat were calculated.

Statistical analyses. One-way ANOVA was used to examine changes in the growth rate of height, weight, and predicted LBM. Also, one-way ANOVA was used to examine the total AUC of glucose, insulin, and C-peptide for the dose effect of tolbutamide during the meal stimulation tests and for the estimates of daily macronutrient intake. The Scheffe multiple comparison test was used to locate significant difference when an ANOVA was significant. Paired $t$ tests were used to evaluate before and after Rx values for LBM measured with ${ }^{18} \mathrm{O}$-water and for the serum concentrations of the 24-h insulin, IGF-I, and IGF-II. A probability level of 0.05 was selected for statistical significance.

\section{RESULTS}

The physical characteristics of the subjects at the initiation of the study (i.e. at the beginning of the Pre-Rx period) are presented in Table 1. On average, the subjects were at the 19 th percentile for height, the 8 th percentile for weight, and were $86 \%$ of the median body weight for height age.

During the course of the Rx period (i.e. mo 4 to 8), one female subject moved from Tanner stage II to Tanner stage III and two male subjects moved from Tanner stage I to Tanner stage II. None of the other nine subjects advanced in maturation level.

Statural growth and weight change. We observed a marked change in linear growth associated with tolbutamide $\mathrm{Rx}$. The effect of Rx on the linear growth rate is shown in Figure 1 for all 12 subjects. During the Pre-Rx observation period, the rate of growth (mean $\pm \mathrm{SEM}$ ) was $0.88 \pm 0.20 \mathrm{~cm} / 4 \mathrm{mo}$. With treatment, linear growth almost tripled to $2.58 \pm 0.31 \mathrm{~cm} / 4 \mathrm{mo}(p$ $<0.05)$. The Post-Rx rate of linear growth was $2.12 \pm 0.16$ ( $p>$ 0.05 versus $\mathrm{Rx}$ period and $p<0.05$ versus Pre-Rx period).

The subgroup in whom TBW was measured $(n=7)$ showed similar changes in growth as compared with the whole group and had a significant increase in linear growth during the $\mathrm{Rx}$. Within this subgroup, multiple comparisons showed that linear growth rate during Pre- $R x(0.83 \pm 0.88 \mathrm{~cm} / 4 \mathrm{mo})$ was significantly less than during $\operatorname{Rx}(2.70 \pm 0.97 \mathrm{~cm} / 4 \mathrm{mo})$ and Post-Rx $(2.25 \pm$ $0.57 \mathrm{~cm} / 4 \mathrm{mo})(p<0.05)$.

Upon excluding the three subjects who changed Tanner stage, we still observed an increase in linear growth during the drug $\mathrm{Rx}$ $(n=9 ; 2.38 \pm 0.37 \mathrm{~cm} / 4 \mathrm{mo})$ that was greater $(p<0.05)$ than the Pre-Rx $(0.84 \pm 0.24 \mathrm{~cm} / 4 \mathrm{mo})$ but not different $(p>0.05)$ from the Post-Rx control period ( $1.94 \pm 0.18 \mathrm{~cm} / 4 \mathrm{mo})$.

Weight increased significantly during all periods of the study 
Table 1. Descriptive data on individual subjects at Pre-Rx period*

\begin{tabular}{|c|c|c|c|c|c|c|c|}
\hline Subject no. & Sex & Age $(y)$ & Height $(\mathrm{cm})$ & Weight $(\mathrm{kg})$ & TS & Pwt/ht & CF score \\
\hline $1 \dagger$ & M & 13.0 & $148.2(16)$ & $35.1(10)$ & I & 88.9 & 98 \\
\hline $2 \dagger$ & $\mathrm{F}$ & 11.7 & $136.5(3)$ & $23.4(5)$ & III & 74.3 & 57 \\
\hline 3 & $\mathrm{~F}$ & 11.1 & $146.6(57)$ & $29.1(10)$ & I & 76.6 & 70 \\
\hline $4 \dagger$ & $\mathrm{F}$ & 12.0 & $130.8(0)$ & $25.0(5)$ & I & 90.9 & 61 \\
\hline 5 & $M$ & 11.1 & $130.1(2)$ & $21.0(5)$ & 1 & 77.8 & 63 \\
\hline $6 \dagger$ & M & 11.0 & $143.5(51)$ & $32.7(25)$ & I & 92.1 & 91 \\
\hline 7 & $\mathrm{~F}$ & 12.2 & $142.6(7)$ & $31.8(10)$ & I & 88.3 & 78 \\
\hline $8 \dagger$ & $F$ & 13.4 & $143.9(1)$ & $31.5(5)$ & II & 86.3 & 93 \\
\hline 9 & $F$ & 6.1 & $112.8(32)$ & $18.1(25)$ & I & 96.5 & 86 \\
\hline $10 \dagger$ & M & 11.5 & $139.0(14)$ & $28.6(10)$ & I & 95.3 & NA: \\
\hline 11 & M & 9.1 & $125.2(9)$ & $21.6(5)$ & I & 88.2 & 42 \\
\hline $12 \dagger$ & M & 11.1 & $130.1(2)$ & $22.0(5)$ & I & 81.5 & 88 \\
\hline Mean \pm SEM & & $11.0 \pm 1.9$ & $135.8 \pm 3.0$ & $26.7 \pm 1.6$ & & $86.4 \pm 2.1$ & \\
\hline
\end{tabular}

* Values in parentheses indicate percentile scores. TS, Tanner staging [breast development for females (F), pubic hair for males (M)]; the only subjects to change Tanner stage during the study were subjects 1 (I to II), 6 (I to II), and 8 (II to III). Pwt/ht, (actual weight/median weight for height agc) $\times 100$; CF score, NIH score for CF.

$\dagger$ Subjects receiving ${ }^{18} \mathrm{O}$-water tests.

$\$ N A, x$-ray not available for scoring.

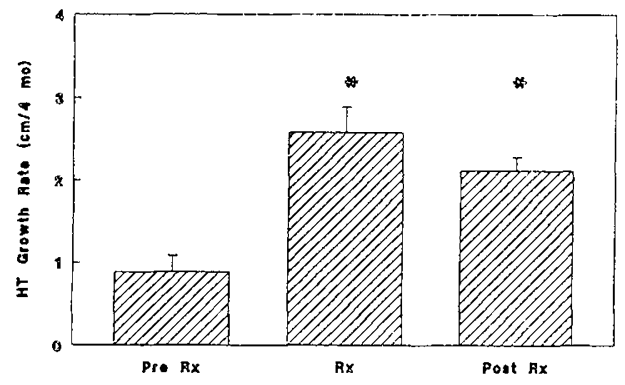

Fig. 1. Height $(H T)$ growth rate $(\mathrm{cm} / 4 \mathrm{mo})$ during Pre-Rx, Rx, and Post-Rx. Mean values are presented; vertical lines represent SEM. *, Rx and Post-Rx are greater than Pre-Rx $(p<0.05)$.

Table 2. Physical characteristics during study (mean \pm SEM)*

\begin{tabular}{|c|c|c|c|c|}
\hline & $0 \mathrm{mo}$ & $4 \mathrm{mo}$ & $8 \mathrm{mo}$ & $12 \mathrm{mo}$ \\
\hline Height $(\mathrm{cm})$ & $135.8 \pm 3.0^{\mathrm{a}}$ & $136.6 \pm 3.0^{b}$ & $139.2 \pm 3.0^{\circ}$ & $141.3 \pm 3.0^{\circ}$ \\
\hline Weight $(\mathrm{kg})$ & $26.7 \pm 1.6^{\mathrm{a}}$ & $27.7 \pm 1.7^{\mathrm{b}}$ & $29.2 \pm 1.7^{c}$ & $29.9 \pm 1.8^{\circ}$ \\
\hline FFW $(\mathrm{kg}) \dagger$ & & $25.3 \pm 1.9^{\mathrm{a}}$ & $27.2 \pm 1.9^{b}$ & \\
\hline Fat $(\mathrm{kg}) \dagger$ & & $4.4 \pm 0.6^{\prime \prime}$ & $3.4 \pm 0.5^{\mathrm{a}}$ & \\
\hline$\%$ Fat $\dagger$ & & $14.7 \pm 1.8^{\mathrm{a}}$ & $10.9 \pm 1.5^{\mathrm{a}}$ & \\
\hline
\end{tabular}

* 0 mo, measurement at beginning of Pre-Rx period; 4 mo, measurement at end of Pre-Rx period: $8 \mathrm{mo}$, measurement at end of Rx: $12 \mathrm{mo}$, measurement 4 mo after end of Rx; FFW, fat-free weight. Values with different superscripts are significantly different.

$\dagger$ Only seven subjects were tested for FFW, fat, and \% fat.

$(p<0.05)$. The rate of weight gain was not significantly different among the Pre- $R x(0.99 \pm 0.26 \mathrm{~kg} / 4 \mathrm{mo}), \mathrm{Rx}(1.50 \pm 0.36 \mathrm{~kg} / 4$ $\mathrm{mo})$, or the Post-Rx $(0.69 \pm 0.30 \mathrm{~kg} / 4 \mathrm{mo})$ periods.

Similar to the group as a whole, the subgroup receiving the TBW test showed no difference in weight gain between Pre- $R x$ $(1.16 \pm 0.56 \mathrm{~kg} / 4 \mathrm{mo}), \mathrm{Rx}(1.06 \pm 0.38 \mathrm{~kg} / 4 \mathrm{mo})$, and Post-Rx $(0.59 \pm 0.82 \mathrm{~kg} / 4 \mathrm{mo})$ periods.

Removing the three maturing subjects did not affect the results for weight gain. For $n=9$, values were: for Pre-Rx, $0.82 \pm 0.33$ $\mathrm{kg} / 4 \mathrm{mo}$; for $\mathrm{Rx}, 1.56 \pm 0.44 \mathrm{~kg} / 4 \mathrm{mo}$; and for Post-Rx, $0.34 \pm$ $0.30 \mathrm{~kg} / 4 \mathrm{mo}(p>0.05)$.

Body composition. Absolute values for LBM and percent fat determined from TBW are presented in Table 2. The accretion of LBM (Fig. 2) as predicted from height was significantly greater during $\mathrm{Rx}$ and Post-Rx compared with the Pre-Rx observation period $(p<0.05)$. There was no difference in LBM accretion between the Rx and Post-Rx periods. The accretion of LBM as measured with ${ }^{18} \mathrm{O}$-water confirms the predicted changes: there was no difference $(p>0.05)$ between the predicted rate $(1.61 \pm$

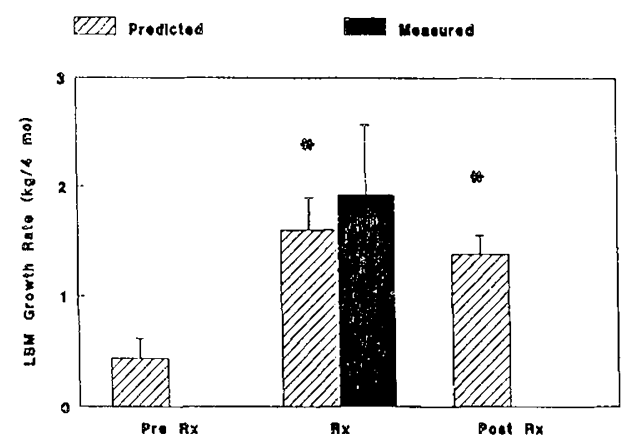

Fig. 2. LBM growth rate $(\mathrm{kg} / 4 \mathrm{mo}$ ) predicted (hatched bars) during Pre-Rx, Rx, and Post-Rx. Measured rate during Rx (solid bar) is also presented. Mean values are presented; vertical lines represent SEM. * $\mathrm{Rx}$ and Post-Rx are greater than Pre-Rx $(p<0.05)$.

$0.29 \mathrm{~kg} / 4 \mathrm{mo})$ and the measured rate $(1.91 \pm 0.65 \mathrm{~kg} / 4 \mathrm{mo})(r$ $=0.72$ ), and the mean value measured at month 8 at the end of $\mathrm{Rx}(27.2 \pm 1.9 \mathrm{~kg})$ was significantly higher than the Pre- $\mathrm{Rx}$ measurement $(25.3 \pm 1.9 \mathrm{~kg})$.

Despite removing the three subjects who increased in Tanner staging, LBM measured with ${ }^{18} \mathrm{O}$-water increased significantly $(p$ $<0.05)$ during the $\mathrm{Rx}(n=4 ; 21.6 \pm 1.0 \mathrm{~kg}$ at month 4 versus $23.8 \pm 1.5 \mathrm{~kg}$ at month $8 ; p<0.05$ ). No difference was observed between the measured increase in LBM and the increase in LBM predicted from height.

Fat mass determined from the TBW tests did not show a change $(4.4 \pm 0.6 \mathrm{~kg}$ before $\mathrm{Rx}$ versus $3.4 \pm 0.5 \mathrm{~kg}$ after $\mathrm{Rx} ; p>$ $0.05)$. The percent body fat determined by TBW was $14.7 \pm$ $1.8 \%$ before $\mathrm{Rx}$ and $10.9 \pm 1.5 \%$ after $\mathrm{Rx}(p>0.05)$.

Acute glucose and hormonal response to tolbutamide. The glucose response to the meal stimulus was different under the conditions of no tolbutamide versus that seen after acute administration of tolbutamide (Fig. 3). The AUC (mean \pm SEM) for glucose concentration was $902 \pm 35,767 \pm 22$, and $755 \pm 33$ $\mathrm{mmol} \cdot \mathrm{min} / \mathrm{L}$ for 0,250 , and $500 \mathrm{mg}$ of tolbutamide, respectively. The AUC for glucose during the 250- and 500-mg Rx were similar $(p>0.05)$; however, AUC for both $\mathrm{Rx}$ were significantly lower compared with the 0 -mg treatment $(p<0.05)$.

The AUC (mean $\pm \mathrm{SEM}$ ) for the insulin response to the meal stimulus was $11129 \pm 1783,12199 \pm 2254$, and $16675 \pm 4997$ $\mathrm{pmol} \cdot \mathrm{min} / \mathrm{L}$ for 0,250 , and $500 \mathrm{mg}$ of tolbutamide, respectively. There was no significant effect of tolbutamide Rx on AUC for insulin $(p>0.05)$.

No effect of tolbutamide was observed on C-peptide concentrations. The mean $( \pm \mathrm{SE})$ areas were $68.8 \pm 6.2,69.0 \pm 10.6$, 


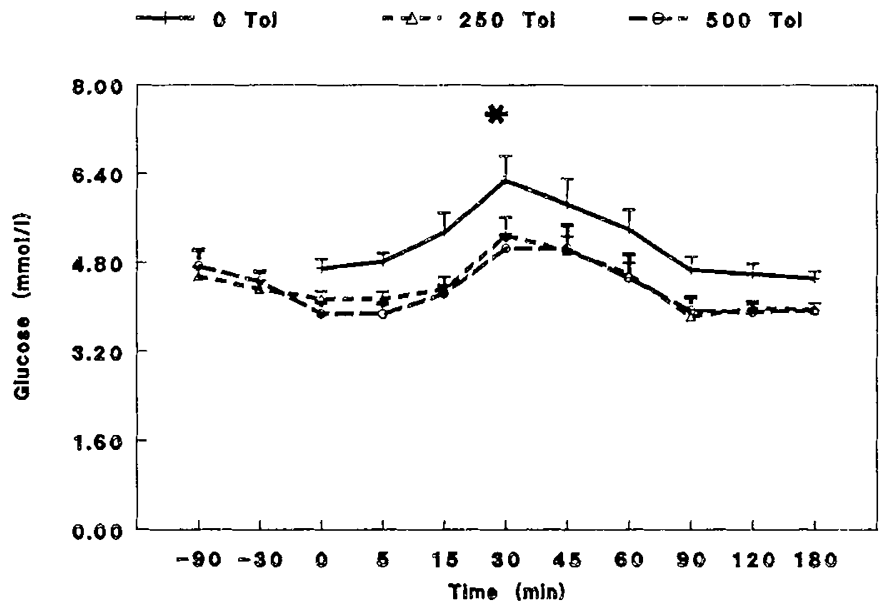

Fig. 3. Glucose response during meal stimulation test after administration of 0,250 , and $500 \mathrm{mg}$ of tolbutamide $(T o l)$. Mean values are presented; bars represent SEM. *, AUC for 250 and $500 \mathrm{mg}$ are less than AUC for $0 \mathrm{mg}$ of Tol $(p<0.05)(n=11)$.

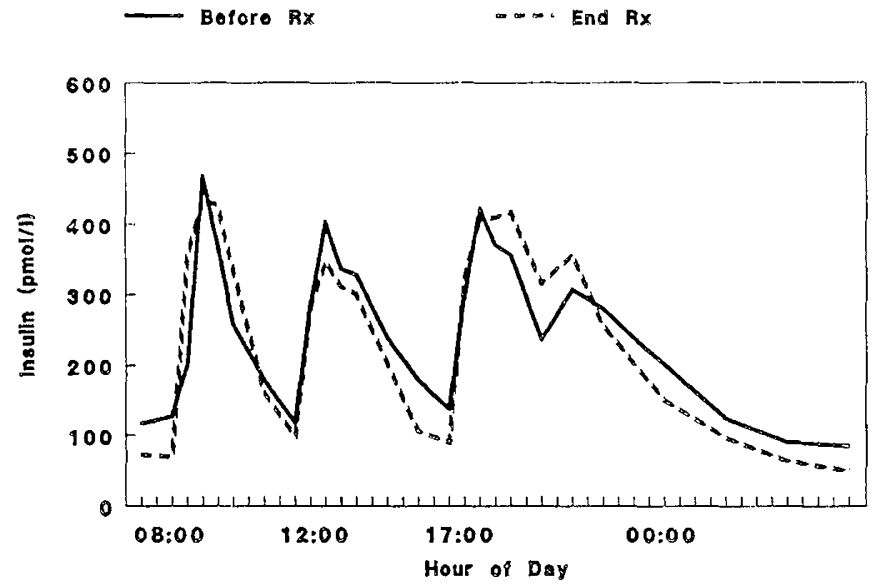

Fig. 4. Serum insulin levels during 24-h assessment before Rx $(0 \mathrm{mg}$ of tolbutamide/day) and after Rx (750 mg of tolbutamide/day). Mean values for 10 subjects are presented. No differences were found between AUC or peak levels at meal times $(p>0.05)$

and $65.7 \pm 13.0 \mathrm{nmol} \cdot \mathrm{min} / \mathrm{L}$ for tolbutamide doses of 0,250 and $500 \mathrm{mg}$, respectively $(p>0.05)$.

Twenty-four h profile of insulin. All subjects had 24-h insulin profiles measured just before and again at the end of the 4-mo treatment period. There was no observed difference in insulin secretion patterns between the two tests (Fig. 4). The integrated insulin area before tolbutamide $\mathrm{Rx}$ was (mean \pm SEM) 301060 $\pm 26483 \mathrm{pmol} \cdot \mathrm{min} / \mathrm{L}$ and after $4 \mathrm{mo}$ of tolbutamide was 293 $289 \pm 37126 \mathrm{pmol} \cdot \mathrm{min} / \mathrm{L}(p>0.05)$. Similarly, there was no significant difference in the average postmeal, peak insulin response before therapy $(487 \pm 35 \mathrm{pmol} / \mathrm{L})$ compared with the end of therapy $(531 \pm 69 \mathrm{pmol} / \mathrm{L})$.

$I G F$. Absolute concentrations of IGF-I and IGF-II did not change significantly with the Rx, although the increase in IGF-I approached significance $(p=0.10)$. The concentrations (mean \pm SEM; $\mathrm{nmol} / \mathrm{L}$ ) of IGF-I were $23.4 \pm 3.1$ and $28.5 \pm 4.4$ before and after Rx, respectively, and the concentrations (mean \pm SEM $\mathrm{nmol} / \mathrm{L}$ ) of IGF-II were $42.0 \pm 2.8$ and $41.2 \pm 2.3$ before and after treatment, respectively. Because IGF-I concentrations are dependent upon maturation level, we transformed IGF values to $z$ scores based on the mean and SD score for each Tanner stage in normal children (Endocrine Sciences) (Fig. 5). The mean of the IGF-I z scores before $\mathrm{Rx}$ was significantly lower than 0 ( $p<$ 0.05 ); however, after $\mathrm{Rx}$, the mean $\mathrm{z}$ score was not significantly different from 0 , implying that the $\mathrm{Rx}$ may have normalized

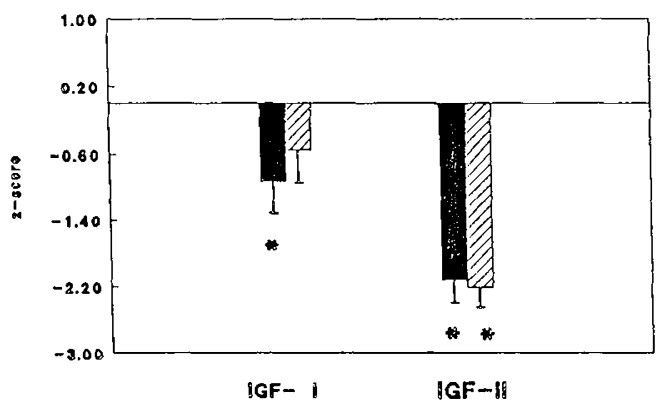

Fig. 5. IGF-I and IGF-II z score transformations before (solid bars) and at the end of (hatched bars) treatment. Means are presented; vertical lines represent SEM. *, Mean values are significantly less than $0(p<$ $0.05)$.

Table 3. Average (mean $\pm S E M$ ) daily intake of energy and macronutrients per $\mathrm{kg}$ body weight for 4-d period during each period of study*

\begin{tabular}{|c|c|c|c|}
\hline & Pre-Rx & $\mathrm{Rx}$ & Post-Rx \\
\hline Energy $(\mathrm{kcal} / \mathrm{kg})$ & $91.9 \pm 21.2$ & $84.7 \pm 26.6$ & $79.2 \pm 26.8$ \\
\hline Protein $(\mathrm{g} / \mathrm{kg})$ & $3.17 \pm 0.72$ & $2.94 \pm 0.92$ & $2.80 \pm 0.84$ \\
\hline Carbohydrate $(\mathrm{g} / \mathrm{kg})$ & $11.9 \pm 2.6$ & $10.6 \pm 3.4$ & $9.6 \pm 4.1$ \\
\hline Fat $(\mathrm{g} / \mathrm{kg})$ & $3.57 \pm 1.03$ & $3.36 \pm 1.19$ & $3.25 \pm 1.02$ \\
\hline
\end{tabular}

$*$ No differences $(p>0.05)$ were found between periods for energy or any nutrient. $n=9$.

IGF-I levels. IGF-II z scores were not different from each other, but both were significantly lower than 0 before and after Rx.

Dietary intake. Four-day prospective diet diaries were obtained 2 to $4 \mathrm{wk}$ before starting tolbutamide, within the last $4 \mathrm{wk}$ of therapy, and within 2 wk of completing the Post-Rx control period. Complete and accurate data were obtained on nine subjects. Analysis of the diary data in absolute units and per kilogram of body weight (Table 3) showed no difference between periods of the study for average daily intakes of energy, protein, carbohydrate, and fat $(p>0.05)$. On a per kilogram of weight basis, the $\mathrm{CF}$ patients consumed approximately 1.5 times the recommended dietary allowance of energy for children and 3 times the recommended dietary allowance of protein for children (23).

\section{DISCUSSION}

The purpose of this study was to determine if the linear growth rate and body composition of children with $\mathrm{CF}$ could be increased through stimulating an increase in insulin secretion and insulin action. The results suggest that the oral hypoglycemic agent tolbutamide increased linear growth and LBM accretion in excess of the control period. The linear growth rate during tolbutamide treatment was comparable to that seen during growth hormone Rx of growth hormone-deficient children (24). The finding of an increased accretion of LBM is particularly important because if most of the increase was in the skeletal muscle, increased skeletal muscle mass could effect a direct improvement in respiratory effort, cough, and pulmonary function as well as increased exercise capability with attendant improvement in the quality of life $(3,25-27)$.

The improved growth rate appears to be caused by the tolbutamide Rx. This is likely mediated by the anabolic effects of increased insulin action or possibly the direct effect of tolbutamide on IGF-I (28). During the study, no other events occurred nor were there other changes in therapy that would be expected to increase growth rate. Although it is possible that by lowering blood glucose, tolbutamide could stimulate appetite, the estimates of daily intake of energy and macronutrients were not different during the control periods or Rx period. Thus, within the limits of the study design, the improved growth would not 
appear to be the consequence of increased caloric intake. Also, the increased growth rate does not seem to be explained by the change in maturation level. The change in two males from Tanner stage I to II would not distort to a great degree our results because most of the male growth spurt occurs between Tanner stages III and IV (29). Possibly, the data on the female subject who moved from Tanner stage II to III could bias the results because the growth spurt in females does occur between these two stages (29). Although this could be a significant confounding variable, analysis of weight gain, linear growth, and LBM without the data on the three subjects who showed some pubertal development did not change the statistical conclusions. During the Post-Rx period, the rate of weight gain was similar to that seen before therapy; however, the linear growth rate remained similar to that of the Rx period. This sustained improvement of linear growth after therapy concluded could indicate persistence of the drug effect. However, because the study design did not include a washout period after the treatment, further studies with alternative designs and controls will be required to answer this question.

Some children with CF have evidence of protein energy malnutrition and impaired growth $(1,3,4,30)$. In this regard, our subjects were not exceptional in that they showed low-percentile weights and heights (Table 1) and low percent body fat (initially $14.7 \%$, Table 2) compared with values based on TBW measurements in normal children ( $\geq 19.5 \%)(21)$. However, our study design used convenience sampling as opposed to random sampling of the C.F population. In addition, the families were allowed to know that the study was designed to evaluate the growthpromoting effects of tolbutamide. As a consequence, our sample is heavily biased towards those children who at the time of recruitment were short and who had shown a noticeable slowing of linear growth. These are serious threats to the external validity of the study if one would attempt to generalize these results to all children with CF. However, because this study was designed to evaluate the growth disorder of CF children, the results may be of particular importance and relevant only to the subgroup of $\mathrm{CF}$ children with the most severe growth problems.

For this group of CF children, we hypothesize that the poor growth is related to the general undernourished state among these subjects and that this is mediated by a relative insulindeficient state. Insulin is a potent anabolic hormone, may be a direct stimulator of other growth factors necessary for normal growth (15-18), and appears to be necessary for normal expression of IGF-I mRNA $(31,32)$. Serum concentrations of insulin are below normal in many children with $\mathrm{CF}(10,12,13)$, and there is a high incidence of glucose intolerance in patients with CF $(10,11)$. Hypoinsulinemia in other conditions such as juvenile onset diabetes mellitus is associated with poor growth and short stature especially with inadequate insulin therapy $(15,33)$. A recent study suggests decreased survival in children with $\mathrm{CF}$ who develop glucose intolerance as opposed to those who do not show this complication (34).

Tolbutamide $\mathrm{Rx}$ in this study appeared to increase insulin action at peripheral sites, i.e. muscle and bone, but did not increase insulin secretion. We derive this conclusion from the dual observations that tolbutamide did effect lower blood glucose concentrations during the meal stimulation tests but had no effect on insulin concentration or C-peptide concentrations during the meal stimulation tests or the 24-h insulin secretion before and at the conclusion of tolbutamide therapy. The lack of an increase in insulin secretion after therapy was not totally unexpected as other researchers have reported that insulin secretion returns to Pre-Rx levels during chronic therapy with similar sulfonylurea agents $(35,36)$. Because insulin secretion did not appear to increase, we speculate that the increased growth and lean tissue deposition during tolbutamide therapy was caused by enhanced insulin action.

The mechanism of improvement in LBM during the tolbutamide therapy could relate to the indirect effects of insulin on carbohydrate utilization and production or to the direct effects of insulin on protein metabolism. Acute fasting tends to cause an increase in leucine oxidation, muscle protein degradation, and hepatic output of glucose; these effects may be related in part to decreased insulin secretion (37-39). Relative to fat as a source of energy, carbohydrate in the presence of insulin spares leucine during semistarvation (40) and glucose infusion in the postabsorptive state tends to suppress glucose production. Thus, if improved insulin action decreases endogenous glucose production, protein degradation might decrease. Insulin also had direct effects on protein turnover, both decreasing muscle protein degradation and increasing muscle protein synthesis (41-43).

Previous research supports our speculation that the observed growth-inducing effect of tolbutamide was related to enhanced insulin action. Craig et al. (44) found that insulin directly increased procollagen mRNA activity in cultured rat osteoblasts. Indirectly, insulin stimulates the production of receptors for IGFI (31), which is known to stimulate growth at the epiphyseal plates $(28,45)$. Abnormally low IGF-I concentrations in malnourished children are associated with statural growth retardation $(46,47)$. Glibenclamide, another oral hypoglycemic agent, has been shown to normalize plasma IGF-I activity and increase skeletal growth in hypophysectomized rats (28). These investigators (28) reported that IGF-I activity was greater in those rats receiving the $\mathrm{Rx}$ versus hypophysectomized controls. In that study, the enhanced IGF-I levels may have been due to the glibenclamide's effect of increasing insulin, although the authors note that insulin levels did not return to normal with the treatment. This leaves open the possibility that the oral hypoglycemic agent directly affects IGF-I levels or bone growth.

In conclusion, nutritional status as indicated by stature and LBM was increased in slowly growing children with CF as a result of a tolbutamide administration. Insulin secretion was not increased, but the improved growth and physical stature of the subjects suggests that direct cellular effects of tolbutamide or indirect effects of tolbutamide on insulin responsiveness in the peripheral tissues improved. Although the findings are provocative, further studies are needed to determine if these effects are transient or are sustainable and to establish whether $\mathrm{Rx}$ with sulfonylurea drugs might constitute a valuable and safe adjunctive therapy for poorly growing children with $\mathrm{CF}$.

Acknowledgments. The authors thank Paulette Snyder, R.N., of the Clinical Studies Center, Susan Jordan, R.D., of the Dietetics Department, and Jonathan Kepner, B.S., and Diane Habash, M.S., of the Nutrition Laboratory for their technical assistance with this study.

\section{REFERENCES}

1. Shepherd R, Cooksley WGE, Cooke WDD 1980 Improved growth and clinical, nutritional, and respiratory changes in response to nutritional therapy in cystic fibrosis. J Pediatr 97:351-357

2. O'Loughlin E. Forbes D. Parsons H. Scott B. Cooper D, Gall G 1986 Nutritional rehabilitation of malnourished patients with cystic fibrosis. Am J Clin Nutr 43:732-737

3. Levy LD, Duric PR, Pencharz PB. Corey ML 1985 Effects of long-term nutritional rehabilitation on body composition and clinical status in malnourished children and adolescents with cystic fibrosis. J Pediatr 107:225230

4. Shepherd RW. Thomas RJ, Bennett D, Cooksley WGE, Ward LC 1983 Changes in body composition and muscle protein degradation during nutritional supplementation in nutritionally growth-retarded children with cystic fibrosis. J Pediatr Gastroenterol Nutr 2:439-446

5. Hubbard VS, Mangrum PJ 1982 Energy intake and nutrition counseling in cystic fibrosis. J Am Diet Assoc 80:127-131

6. Shepherd RW. Holt TL. Vasques-Velasquez L. Coward WA. Prentice A. Lucas A 1988 Increased energy expenditure in young children with cystic fibrosis. Lance1 1:1300-1303

7. Vaisman N, Pencharz PB, Corey M, Canny GJ. Hahn E 1987 Energy expenditure of patients with cystic fibrosis. J Pcdiatr 111:496-500

8. Gerson WT, Swan P, Walker WA 1987 Nutrition support in cystic fibrosis. Nutr Rev 45:353-360

9. Moore MC. Greene HL, Donald WD. Dunn GD 1986 Enteral-tube feeding as adjunct therapy in malnourished patients with cystic fibrosis: a clinical study and literature review. Am J Clin Nutr 44:33-41 
10. Handwerger S, Roth J, Gorden P, Di Sant' Agnese P, Carpenter DF, Peter G 1969 Glucose intolerance in cystic fibrosis. N Engl J Med 281:451-46I

11. Stutchfield PR, O'Halloran S, Teaie JD, Isherwood D, Smith CS, Heaf D 1987 Glycosylated haemoglobin and glucose intolerance in cystic fibrosis. Arch Dis Child 62:805-810

12. Milunsky A. Bray GA, Londono J, Loridan L 197 I Insulin, glucose, growth hormone and free fatty acids-determinations in patients with cystic fibrosis. Am J Dis Child 121:15-19

13. Zipf WB, McCoy K, O'Dorisio TM 1986 Effects on glucose and insulin of GIP (gastric inhibitory peptide) normalization by exocrine replacement in cystic fibrosis. Pediatr Res 20:337A(abstr)

14. Moran A. Diem P. Klein DJ, Levitt MD, Robertson RP 1991 Pancreatic endocrine function in cystic fibrosis. J Pediatr 1 18:715-723

15. Mabry CC 1979 Permanent growth impairment due to early deprivation of insulin in juvenile onset diabetes mellitus. Pediatr Res 13:478(abstr)

16. Heinze E, Beischer W, Teller WM 1978 Insulin secretion in growth hormone deficient children and the effect of the sulfonylurea drug glibenclamide on linear growth. Eur J Pediatr 128:41-48

17. Farber S 1944 Pancreatic function and disease in early life. Virchow Arch Path Anat $37: 238-250$

18. Larrson Y 1958 The islets of Langerhans in pancreatic fibrosis. Pediatrics 21:893-902

19. Slaughter MH, Lohman TG, Boileau RA, Christ CB 1987 An objective method for measurement of musculo-skeletal size in children and youth. J Sports Med Phys Fitness 27:461-472.

20. Schoeller DA, Dietz W. Van Santen E, Klein PD 1982 Validation of saliva sampling for total body water determination by $\mathrm{H}_{2}{ }^{18} \mathrm{O}$ dilution. Am $\mathrm{J}$ Clin Nutr 35:591-594

21. Boileau RA, Lohman TG, Slaughter MH. Ball TE. Going SB, Hendrix MK 1984 Hydration of the fat-free body in children during maturation. Human Biology 56:651-666

22. Pennington JAT 1989 Bowes and Church's Food Values of Portions Commonly Used. JB Lippincott, Philadelphia

23. Committee on Interpretation of RDAs 1989 Recommended Dietary Allowance. National Academy of Science, Washington. DC

24. Sherman BM, Frane J, Johanson AJ, Kaplan SL 1988 Predictors of response to treatment with methionyl human growth hormone. In: Underwood LE (ed) Human Growth Hormone Progress and Challenges. Marcel Dekker. New York, pp 131-144

25. Arora NS, Rochester DF 1982 Effect of body weight and muscularity on human diaphragm muscle mass, thickness, and area. J Appl Physiol 52:6470

26. Orenstein DM, Henkc KG, Cerny FJ 1983 Exercise and cystic fibrosis. Physician Sportsmed 11:57-63

27. Gibson JNA. Halliday D, Morrison WL, Stoward PJ, Hornsby GA. Watt PW, Murdoch G, Rennie MJ 1987 Decrease in human quadriceps muscle protein turnover consequent upon leg immobilization. Clin Sci 72:503-509

28. Heinze E, Ranke M. Manske E, Vetter U, Voigt KH 1982 The effect of glibenclamide on plasma insulin, plasma somatomedin bioactivity and skeletal growth in hypophysectomized rats. Acta Endocrinol (Copenh) 101:187192
29. Marshall WA, Tanner JM 1970 Variations in the pattern of pubertal changes in boys. Arch Dis Child 45:13-23

30. Soutter VL, Kristidis P, Gruca MA. Gaskin KJ 1986 Chronic undernutrition/ growth retardation in cystic fibrosis. Clin Gastroenterol 15:137-155

31. Murphy LJ 1988 Impaired estrogen-induced uterine insulin-like growth factorI gene expression in the streptozotocin diabetic rat. Diabetologia 31:842847

32. Salamon EA, Luo J, Murphy LJ 1989 The effect of acute and chronic insulin administration on insulin-like growth factor-I expression in the pituitaryintact and hypophysectomized rat. Diabetologia 32:348-353

33. Hindmarsh PC. Matthews DR, DiSilvio L. Kurtz AB, Brook CGD 1988 Relation between height velocity and fasting insulin. Arch Dis Child 63:665666

34. Finkelstein SM, Wielinski CL, Elliott GR, Warwick WJ, Barbosa J, Wu SC, Klein DJ 1988 Diabetes mellitus associated with cystic fibrosis. J Pediatr $112: 373-377$

35. Reaven G, Dray J 1967 Effect of chlorpropamide on serum glucose and immunoreactive insulin concentrations in patients with maturity-onset diabetes mellitus. Diabetes 16:487-492

36. Feldman JM, Lebovitz HE 1971 Endocrine and metabolic effects of glibenclamide. Evidence for an extrapancreatic mechanism of action. Diabetes 20:745-755

37. Millward DJ, Waterlow JC 1978 Effect of nutrition on protein turnover in skeletal muscle. Federation Proc 37.2283-2290

38. Nair KS, Woolf PD, Welle SL, Matthews DE 1987 Leucine, glucose, and energy metabolism after 3 days of fasting in healthy human subjects. Am J Clin Nutr 46:557-562

39. Vazquez JA, Paul HS, Adibi SA 1986 Relation between plasma and tissue parameters of leucine metabolism in fed and starved rats. Am J Physiol 350:E615-E621

40. Vazquez JA, Morse EL, Adibi SA 1985 Effect of dietary fat, carbohydrate, and protein on branched-chain amino acid catabolism during caloric restriction. J Clin Invest 76:737-743

41. Abumrad NN, Jefferson LS, Rannels SR, Williams PE, Cherrington AD, Lacy WW 1981 Role of insulin in the regulation of leucine kinetics in the conscious dog. J Clin Invest 70:1031-1041

42. Millward DJ, Odedra B, Bates PC 1983 The role of insulin, corticosterone and other factors in the acute recovery of muscle protein synthesis on refeeding food-deprived rats. Biochem J 216:583-587

43. Fulks RM, Li JB, Goldberg AL 1975 Effects of insulin, glucose, and amino acids on protein turnover in rat diaphragm. J Biol Chem 250:290-298

44. Craig RG, Rowe DW, Petersen DN, Kreams BE 1989 Insulin increases the steady state level of 1 (I) procollagen $\mathrm{mRNA}$ in the osteoblast-rich segment of fetal rat calvaria. Endocrinology 125:1430-1437

45. Soliman AT, Hassan AEHI, Aref MK. Hintz RL, Rosenfeld RG, Rogol AD 1986 Serum insulin-like growth factors I and II concentrations and growth hormone and insulin responses to arginine infusion in children with proteinenergy malnutrition before and after nutritional rehabilitation. Pediatr Res energy malnutritio

46. Hintz RL, Suskind R, Amatayakul K, Thanangkul O, Olson R 1978 Plasma somatomedin and growth hormone values in children with protein-calorie malnutrition. J Pediatr 92:153-156

47. Grant DB, Hambley J, Becker D, Pimstone BL 1973 Reduced sulphation factor in undernourished children. Arch Dis Child 48:596-600 